San Jose State University

SJSU ScholarWorks

Master's Theses

Master's Theses and Graduate Research

1989

\title{
Zoogeography and systematics of the new guinea tree monitor lizards (Sauria: varanidae)
}

Robert George Sprackland

San Jose State University

Follow this and additional works at: https://scholarworks.sjsu.edu/etd_theses

\section{Recommended Citation}

Sprackland, Robert George, "Zoogeography and systematics of the new guinea tree monitor lizards (Sauria: varanidae)" (1989). Master's Theses. 3227.

DOI: https://doi.org/10.31979/etd.hvgn-8ert

https://scholarworks.sjsu.edu/etd_theses/3227

This Thesis is brought to you for free and open access by the Master's Theses and Graduate Research at SJSU ScholarWorks. It has been accepted for inclusion in Master's Theses by an authorized administrator of SJSU ScholarWorks. For more information, please contact scholarworks@sjsu.edu. 


\section{INFORMAFION TO USERS}

The most advanced technology has been used to photograph and reproduce this manuscript from the microfilm master. UMI films the text directly from the original or copy submitted. Thus, some thesis and dissertation copies are in typewriter face, while others may be from any type of computer printer.

The quality of this reproduction is dependent upon the quality of the copy submitted. Broken or indistinct print, colored or poor quality illustrations and photographs, print bleedthrough, substandard margins, and improper alignment can adversely affect reproduction.

In the unlikely event that the author did not send UMI a complete manuscript and there are missing pages, these will be noted. Also, if unauthorized copyright material had to be removed, a note will indicate the deletion.

Oversize materials (e.g., maps, drawings, charts) are reproduced by sectioning the original, beginning at the upper left-hand corner and continuing from left to right in equal sections with small overlaps. Each original is also photographed in one exposure and is included in reduced form at the back of the book.

Photographs included in the original manuscript have been reproduced xerographically in this copy. Higher quality $6^{\prime \prime} \times 9^{\prime \prime}$ black and white photographic prints are available for any photographs or illustrations appearing in this copy for an additional charge. Contact UMI directly to order.

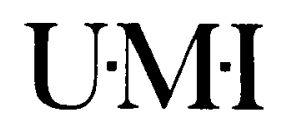

University Microfilms International

A Bell \& Howell Information Company 
- 
Order Number 1399653

Zoogeography and systematics of the New Guinea tree monitor lizards (Sauria:Varanidae)

Sprackland, Robert George, M.A.

San Jose State University, 1989 
ZOOGEOGRAPHY AND SYSTEMATICS OF THE NEW GUINEA

TREE MONITOR LIZARDS (SAURIA: VARANIDAE)

\author{
A Thesis \\ Presented to \\ The Faculty of the \\ Department of Biological Sciences \\ San Jose State University
}

In Partial Fulfillment

of the Requirements for the Degree

Master of Arts

By

Robert George Sprackland

December, 1989 


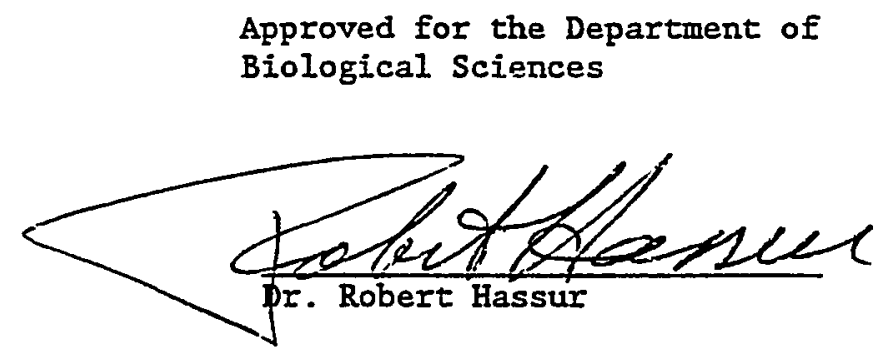

Vida C. Ka nl

Dr. Vida Kent
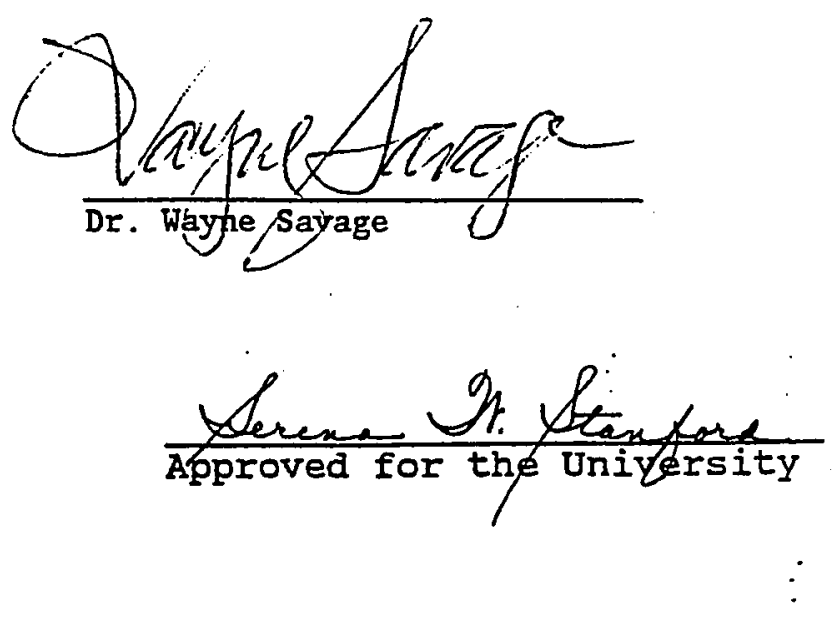


\title{
ZOOGEOGRAPHY AND SYSTEMATICS OF THE NEW GUINEA TREE MONITOR IIZARDS (SAURIA: VARANIDAE)
}

\author{
Robert George Sprackland
}

\begin{abstract}
The systematics of tree monitors is cladistically assessed in comparison with 18 other species of varanid lizards. Based on features of scalation, color, morphology and distribution, five taxa are recognised: Varanus prasinus, $\underline{v}$ bogerti comb. nov., $\underline{v}$ beccarii comb. nov., $\underline{v}$. teriae, sp. nov., and $\underline{v}$. telenesetes sp. nov. This assemblage is accorded subgeneric status as Chondrovaranus, subgen. nov., and is shown to be closely allied to $\underline{v}$. indicus and not, as previously thought, to the subgenus odatria. Using distribution and character analysis, an evolutionary model for tree monitors is presented.
\end{abstract}

Key words: Monitor lizard, Varanus, evolution, zoogeography, cladistics, Varanus prasinus, systematics. 
Tree monitors represent a closely allied group of medium sized lizards that range across the entirety of New Guinea (Boulenger, 1885: DeRooij, 1915; Mertens, 1942C, 1950, 1959; Allison, 1982) and extreme northeastern Australia (Cogger, 1975; Czechura, 1980). They are characterized by an elongated body and limbs, and a fully prehensile tail (Greene, 1986) which is at least 1.75 times the snout-vent length (SVL). Most widespread of these lizards is the striking emerald, or green, tree monitor, Varanus prasinus. The adaptations for arboreality all represent highly derived characters within the Varanidae (Greene, 1986).

Mertens $(1942 a, c)$ assigned Varanus prasinus to the subgenus odatria primarily on the basis of its round tail, but acknowledged that prasinus was unlike other odatrians. Mertens (1941, 1942a, C, 1950) placed four subspecies under prasinus; prasinus, kordensis, beccarii, and bogerti. My own observations on a number of varanid species, inciuding several odatria and $v$. prasinus, suggested that the prasinus-group is distinct enough in habits, ecology, and morphology to warrant separation from odatria. In addition, two taxa reported by Czechura (1980) were assigned to $y_{\text {. prasinus, though careful }}$ examination indicates these represent new species. 
This paper presents a systematic review of the tree monitors to establish their affinities among themselves and within the Varanidae. This study concludes that (1) two subspecies previously assigned to $\underline{V}$. prasinus be elevated to specific status, (2) the subspecies kordensis, representing normal variation within prasinus, be placed in junior synonomy with prasinus, (3) Australian and Rossell Island lizards represent new species, (4) this assemblage represents a subgenus distinct from odatria and Euprepiosaurus, and (5) is directly descended from Varanus salvator-related varanids and not from odatria.

\section{MATERIALS AND METHODS}

Forty six prasinus-group lizards were examined for meristic characters, color patterns, ecology, and behavior. Live specimens of $\underline{V}$. prasinus and $\underline{V}$. beccarii were examined in zoos and private collections.

Fifty-eight traits were tabulated for 23 varanid species to determine relationships of the prasinus-group to varanidae in general (Tab. 1). A character was assigned ancestral status (0) if it was common in related, non-varanid outgroups (helodermids, lanthanotids, anguids) (Pregill et al., 1986). Thus, a round nostril condition, common to most lacertilians, is rated as ancestral, while a slit nostril is considered derived. McDowell and Bogert (1954) point out that in varanids, the elongation of the snout is a secondary 
(=derived) condition that preceded the forward placement of the nostrils. Consequently, an ancestral varanid is expected to have an elongated snout with a posterior nostril (0) (i.e., Varanus griseus). In non-varanid outgroups, the adpressed limbs do not meet, so this was taken as the ancestral condition. Other traits were assessed similarly.

Antiserum/antigen data obtained by Baverstock (pers. comm.) have been incorporated in the cladograms. Karyotype data were derived from Holmes et al. (1975) and Auffenberg (1980, 1988). Hemipenal data are from Branch (1982) and Bohme (1988). Some information on cranial morphology was taken from Mertens (1942b). Other lata were taken from speciuens at the institutions listed below. A cladogram (Fig.1) was constructed using the PAUP (Phylogenetic Analysis Using Parsimony) program.

Specimens were examined from: American Museum of Natural History (AMNH); Field Museum of Natural history (FMNH); Queensland Museum (QM); Florida State Museum (FSM); Carnegie Museum of Natural History (CM); U.S. National Museum of Natural History (USNM); University of Texas at Arlington (UTACV); University of Kansas (KUMNH); California Academy of Sciences (CAS); Museum of Vertebrate Zoology (MVZ); Museum of Comparative Zoology (MCZ); San Jose State University (SJSU), and the author's collection (RGS).

\section{RESULTS}

The PAUP-generated cladogram is given in Fig. 1. The 58 character states and character distribution among 23 varanid 
taxa are given in Table 1. Several trends become apparent from examination of Fig. 1 .

First, Varanus griseus is closest to the ancestral condition for extant varanids. Ancestral characters for this taxon include a round tail, elongated, broad snout with a posterior nostril, fused nasal bones, a short tongue, a thin tearoral arch, and a square snout. Griseus ranges across eastern north Africa through Asia Minor east to India. In Africa, it gave rise to the exanthematicus-niloticus group. Bohme (1988) has elevated albigularis to specific status from exanthematicus, and the remaining African taxa may similarly need revision. In any event, griseus is only marginally sympatric with other African monitors. Bohme (1986) retains griseus in the monotypic subgenus psammosaurus. He further assigns both exanthematicus and niloticus to polydaedalus, while removing exanthematicus from Empagusia. This study concurs with both assignments.

The eastern limit of the range of $\underline{v}$.griseus borders with bengalensis and flavescens. These Asian species are closely allied to rudicollis and dumerilii, and have been assigned to the subgenus Empagusia by Bohme (1986), to which I add the Philippine olivaceus.

From this point, another two major lines diverged; the primarily Australian monitors, characterized by small, pebbled cranial scales, comparatively short tails, and terrsetrial habits, and the Indo-New Guinean monitors that retain large, polygonal cranial scales, relatively long tails and 
arboreal/semi-aquatic habits. In the first group are two subgenera. Varanus includes varius, komodoensis, gouldii, panoptes and mertensi (and probably rosenbergi, which was unavailable for this study), all species that exceed one meter in total length (TL). The other subgenus is odatria, typicaliy under one meter TL, with round, keeled tails. Except for Varanus (Odatria) timorensis (hypothesized as most ancestral), the subgenus is endemic to Australia.

Varanus salvator may warrant a subgenus of its own (Bohme, 1986), for which no established name is available. Varanids assigned to the species salvator are highly variable in size, color, pattern and distribution, and include such diverse taxa as melanistic giants from the Nicobar Islands to bright yellow and brown forms in the Philippines, suggesting that the entire "salvator" group requires revision.

Varanus indicus is assigned to the subgenus Euprepiosaurus (Bohme, 1986), to which V. karlschmidti may be added (Baverstock, pers. comm.). However, differences between the prasinus-group and indicus are significant, for which reason I place the former in the

Subgenus CHONDROVARANUS, subgen. nOv. Diagnosis: Medium sized (to $1 \mathrm{M}$ total length) lizards characterized by (1) elongated body, neck, limbs, digits and tail; (2) tail round in section, (3) tail fully prehensile: (4) nostril round or slightly oval, (5) nostril positioned midway between snout tip and orbit; (6) nasals fused; (7) 
premaxillary teeth 9, maxillary 10, dentary 11; (8) supraoculars transversely dilated; (9) preocular streak absent; (10) canthus rounded; (11) cranial scales large, polygonal, glossy; (12) maxillary region flat, not swollen, (13) snout triangular in sectional aspect, and (14) preanal pores absent.

Characters $1,2,3,4,5,9,10,13$, and 14 are synapomorphic (=shared derived characters) to tree monitors. Characters $2,3,5,7,9,10$ and 14 separate Chondrovaranus from lizards of the subgenus Varanus (komodoensis, gouldii, varius) and salvator (subgenus uncertain, Bohme, 1986). Characters $1,3,5,6,7,8,9,10,11$ and 12 separate it from odatria. Though closely allied to Euprepiosaurus (Bohme, 1986), including $V_{\text {. }}$ indicus (Bohme, 1986) and karlschmidti (Baverstock, pers. comm.), characters 1, 2, 3, 7, 9, 13 and 14 distinguish Chondrovaranus from the latter.

Comments: Chondrovaranus is clearly derived from the salvator-indicus lineage of varanids as evidenced primarily by cranial lepidosis and skull morphology. It is distinct enough in color, habits, ecology and morphology to warrant separation from allied taxa (Fig. 1). The green coloration, highly prehensile tail and arboreal habits all suggest this easternmost radiation of varanids is among the most highly derived and, consequently, among the most recently evolved members of the family. The apparent lack of vagility seen in 
the distribution of Chondrovaranus compared to Euprepiosaurus or salvator is assumed to reflect this recency of evolution, though the subgenus is moving from a mainland New Guinea epicenter to occupy islands and adjacent Australia.

VARANUS PRASINUS (Schlegel) 1839.

Figs. 2, 3, 4

1831 Monitor viridis Gray, in Griffith, Animal Kingdom 9, p.26, type locality not given.

1839 Monitor prasinus Schlegel, Abb. Amphib., p. 78, tab. 22, Fig. 5 (Fig. 2), type locality Fort de Bus, westcoast of New Guinea.

1845 Hydrosaurus prasinus Gray, Cat. Lizards Brit. Mus., p. 13 .

1856 Varanus prasinus Bleeker, Reis Minahassa 1, p. 278.

1874 Monitor kordensis Meyer, Mber. Berl. Akad. p.131, type locality wiak Island (Kordo).

1877 Odatria prasina Gunther, Ann. Mag. Nat. Hist.,19:413, Torres Straits Islands.

1885 Varanus kordensis Boulenger (part), Cat. Lizards Brit. Mus. vol. 2, p. 322 .

1915 Varanus kordensis De Rooij (part), Rept. Indo-Austr. Arch., 1, p.152, Fak Fak, Kordo.

1942 Varanus prasinus prasinus Mertens, Abh. Senck. Naturf. Gesell., 466, p.292.

Varanus prasinus kordensis Mertens, ibid, p. 295. 
Specimens examined: UTACV 6736, 6744, 6816; FMNH 14102- 3; AMNH 99610, 59051, 101071, 92335, 92337, 59053, 99611, 92371, 92663, 105877-8; MCZ 149745-6, 141304, 140843, 126800-01, 137514, 4435, 137529-30, 10119, 126798; USNM 195775 (3 sp): CAS 135589, 126909, 20900, 126922; RGS 100, 101; MVZ 74904-5; plus 7 living animals.

Diagnosis: Color green, with black chevrons dorsally, unpatterned below. Nuchals round or oval, smooth or with slight keel. Distinct from beccarii, teriae, and bogerti on the basis of color and smoother condition of nuchals. It differs from telenesetes in having black, not pale, palmar surfaces, and in having an unpatterned ventral coloration. Description: Snout long, depressed at tip. Canthus rostralis indistinct, swollen around nostrils. Nostrils round, median between orbit and snout tip. Upper labials flat, smooth and distinct, 22-23 in number. Cephalic scales large, polygonal, smooth or with minute pits. Sutures between cephalic scales shallow, giving a predominantly smooth texture. Supraoculars 3-7, transversely elongated. Scales from rictus to rictus 32-42. Nuchal scales are round or oval, anterior scales larger and smoother than posterior (though they occasionally shrink and become keeled from preservation). Posterior nuchals with single, posterior apical pit. 
Dorsal scales slightly oval, becoming oval along sides, structure as posterior nuchals. Midbody scales in 80-112 rows. Ventral scales in 71-90 rows, very feebly keeled, of salvatortype structure (Fig. 3) .

Adult SVL ranges from $125-290 \mathrm{~mm}(x=226.4)$, TL $463-874 \mathrm{~mm}$ $(x=653.7)$

Scales are green, ranging from dark jade to lime, the labials often marked with black spots. The epidermis between scales is velvet black, forming 6-8 crosshands in some individuals (Fig. 2a). Sometimes these bands are lacking, the green scales forming close-knit, indistinct concentric rings (Fig 2b); the latter, once assigned to the subspecies kordensis (see below) is found throughout the range of prasinus, and from the same sites of the banded morph. There is no trace of a temporal streak. Ventrally uniform green in color. The throat is yellowish, sometimes with grayish crossbands.

Distribution: New Guinea mainland, in lowland forests below 5,000 feet; absent from the mountains (Fig. 4).

Remarks: Literature reviews of $\underline{v}$. prasinus and kordensis provide numierous minor differences between the taxa, to the extent that Mertens (1941) placed kordensis as a subspecies of prasinus. His decision was based on only two animals and one skull with which to work (Mertens, 1942c, p. 295). Most characteristic of these lifferences has been the keeled nature of the nuchals in kordensis. Having observed living specimens of these lizards, the nuchals are smooth 
anteriorly, but tend to become oblong and somewhat keeled posteriorly. In specimens of prasinus (sensu Mertens, 1942C), preservation often causes a shrinking of these scales, making all nuchals appear oval and keeled. This character has not proved to be a reliable discriminant for either live or preserved tree monitors.

Boulenger (1885) noted that the body scales of kordensis are elongated, but observation shows that so are the lateral body scales of prasinus generally. Boulenger's description of kordensis is based on two specimens, one from kordo (type locality), the other from "New Guinea, South of Huon Gulf." The latter is also described as "entirely black" and most likely represents bogerti. As a note of importance, Boulenger describes prasinus as having caudal scales "not keeled" and "keeled" in the same paragraph, probably reflecting the variable effect of preservation on scutellation. DeRooij (1915) describes kordensis similarly to Boulenger, adding that the tail is 2.33 times SVL (cf. 1.75 times SVL in prasinus). In measuring 40 lizards for this feature, no clear pattern was found in tail length/sVI ratio, either clinally from east to west, or by population within any given area. DeRooij also describes kordensis as being either black or olive with dark crossbands. In listing the habitat, she indicates that the only specimens she examined personally were from the Aru Islands, which are clearly assignable to 
beccarii. The remaining localities given include much of New Guinea, and include, most likely, descriptions of bogerti and prasinus taken from other workers.

The most visible distinction between lizards dubbed kordensis and prasinus is color pattern, which is what Meyer (1874) used as the principal justification for naming the new species. In the former, dorsal bands of green are formed from large occelli, giving the dorsum a spotted appearance unless the lizard is distended with air. prasinus is clearly banded with green, occelli being distinguishable only in juveniles or along the spine. Kordensis tends to be darker green (jade) than prasinus (lime). However, the geographical distribution of these patterns is random, showing no cline or population centers. Given that the only difference separating these taxa is minor color variation, retention of kordensis as a subspecific entity is unwarranted, and is herein placed in junior synonomy with prasinus.

\section{VARANUS TELENESETES, Sp. NOV.}

$$
\text { Figs. 5, } 6
$$

1980 Varanus prasinus Czechura, Mem. Old. Museum, 20(1):103-9. Specimen examined: QD J1190, Roussell (Rossel) Island, Milne Bay Province, Papua New Guinea.

Diagnosis: similar to $\underline{V}$. prasinus from which it differs in having light, not black, palmar surfaces, smooth ventral scales, and a mottled ventral pattern. 
Description: Known only from the type. SVL $217 \mathrm{~mm}$.; tail $425 \mathrm{~mm}$. Nuchal scales round, feebly keeled (possibly from preservation), equal in size to dorsals. Snout depressed, broad at tip. Nostril round, midway between orbit and snout tip. Upper labials 22, solid in color. Supraoculars enlarged, 7 in number. Scales across rictus 36. Tongue light in color, probably yellowish in life. Cranial scales large, flat and smooth. Gular scales small, round, flat. Midbody scales in 100 rows. Ventrals in 92 rows, smooth. Palmar surfaces with conical pads, pale in color. Claws short, compressed. Caudals feebly keeled. Adpressed limbs meet and overlap.

In color, similar to $\underline{v}$. prasinus, being green above, with indistinct dark chevrons, apices pointed posteriorly. Ventrally mottled cream and dark brown. Throat banded.

Remarks: Mertens (1959) examined a varanid from Rossel Island which he assigned to $\underline{V}$. prasinus bogerti, but the Queensland Museum specimen bears no resemblence to bogerti. Aside from the distinct coloration, the snout of telenesetes is broader and blunter than that of bogerti; telenesetes is further distinct from bogerti in having smooth cranial scales, fewer scales across the rictus (36 cf. 44-48), feebly keeled (vs. tubercular) nuchals, and feebly keeled (vs. strongly keeled) dorsal scales.

V. telenesetes appears to represent a relict population that arrived on Rossel Island when there was a land link to 
mainland New Guinea, suggested by the zoned distribution of the tree monitors, and the lack of vagility demonstrated in their dispersal. The name telenesetes is from the Greek, "far island dweller," noting the occurrence of this species at the easternmost point of New Guinea, and some 330 kilometers from the next nearest tree monitor population.

VAPBMSS TERIAE, Sp. NON.

Figs. 7,8

1980 Varanus prasinus prasinus, Czechura, Mem. Qld. Museum, $20(1): 103-9$.

Specimens examined: QD J31566 (holotype), J35450, J35451 (paratypes); Buthen Buthen, Nesbit River, Cape York Peninsula, Queensland, Australia.

Diagnosis: A predominantly melanistic lizard, with light bluish-green snout tip, yellow dorsal spots forming thin, paired chevrons and caudal rings, a pronounced temporal streak, and a pale yellowish ventor, readily distinguished by color and pattern from all other tree monitors. It is further distinguishable by the presence of conical, not flat, gular scales, a more anterior nostril, and by a more robust appearance, especially the postocular region.

Description: SVL 225-254 mm. Tail 450-513 mm. Snout not depressed at tip. Nostril oval, slightly nearer tip of snout than eye. Six or seven transversely dilated supraoculars. Upper labials 21-23, uniformly colored. Gular scales conical, pointed. Anterior nuchals round, smooth; anterior nuchals 
ovoid, slightly keeled, subequal with dorsals. Midbody scales in 90-93 rows. Ventrals in 84-91 rows, smooth. Adpressed limbs meet and overlap. Tail at least 1.75 times SVL, round in section, distinctly keeled.

Measurements for the type series are given:

$$
\text { J31566 (Type) }
$$

SVI

Tail

snout-orbit

Vent. scale rows

Midbody rows

scales across rictus 36

Sex
254

513

21

84

93

M
J35450

252

500

22

86

90

36

$\mathbf{M}$
J35451

225

450

19

91

90

36

F

In color, $\underline{v}$ teriae is black above, with a bluish-green upper snout, from tip to interorbital area. The body has small, yellow dots that form indistinct, paired chevrons that become caudal bands. A pale cream or yellow temporal streak extends from the posterior rim of the orbit 3-5 mm past the upper point of the ear, and is bordered above by a darker stripe. Ventral coloration is a pale lime green, including the ventral aspects of the limbs. The palmar surfaces are black, and covered with conical scales.

Remarks: Color, pattern, and the conical gulars readily separate teriae from other tree monitors. From beccarii it is further distinguished in having slightly keeled (cf. strongly 
keeled) nuchals, smooth ventrals, higher ventral scale count (84-91 cf. 70-79), and higher midbody scale count (90-93 cf. 81-86). From bogerti it is distinguished by a higher snout (tip depressed in bogerti), shallower suture lines between craniai scales (giving teriae a smoother cranial texture) and slightly keeled nuchals (cf. strongly keeled).

This species is named for my wife, Teri Ann Sprackland.

VARANUS BOGERTI MERTENS 195n, COmb. NOV.

Figs. 6, 9

1950 Varanus prasinus bogerti, Mertens, Amer. Museum Novitates 1456:3-6, Fergusson Island.

1885 Varanus kordensis part, Boulenger, Cat. Lizards Brit. Museum, II:322 (New Guinea, South of Huon Gulf).

1895 Varanus kordensis, Boulenger, Ann. Mag. Nat. Hist. 16 (ser 6), Fergusson Island.

1915 Varanus kordensis part, DeRooij, Reptiles Indo-Aust. Arch., p. 152 (Ferguson, Trobriand).

Specimens examined: AMNH 41639 (type), 41638 (paratype), Fergusson Island, Milne Bay Province, Papua New Guinea; 76722, Waikaiana, Normanby Island, Milne Bay Province, Papua New Guinea.

Diagnosis: A melanistic monitor lacking all trace of pattern. From beccarii it is distinguished by higher midbody scale count (95-99 cf. 81-86), higher ventral count (87-90 cf. 70-79), very rugose upper cranials, and a greater number of scales from rictus to rictus (44-48 cf. 32-37). The 
tubercular, sharply keeled nuchals, rugose cranials, and color distinguish bogerti from the remaining tree monitors.

Description: As given by Mertens (1950), with the modification that nostril position in bogerti is not appreciably posterior to that of beccarii.

Remarks: Bogerti and prasinus come closer to sympatry than any other two members of the tree monitor group. Bogerti is known from Fergusson and Normanby Islands, while prasinus is recorded for Goodenough (Burt and Burt, 1932; Mertens 1950), all in the same archipelago.

VARANUS BECCARII (DORIA) 1874 , COMb. NOV. Figs. 3, 10

1874 Monitor beccarii, Doria, Ann. Museum Civ. Stor. Nat. Genova 6:331-332 (Wokan, Aru islands, New Guinea).

1885 Varanus kordensis part, Boulenger, Cat. Lizards Brit. Museum, II: 322 .

1915 Varanus kordensis part, DeRooij, Repts. Indo-Austr. Arch., I:152 (Aru Islands).

1941 Varanus prasinus beccarii, Mertens, Senckenbergiana $23: 272$.

Specimens examined: MCZ 7489 (2 specimens), Aru Islands; plus 4 live specimens. Diagnosis: Melanistic, with triangular keeled nuchal scales. Differs from bogerti (q.v.) in having lower scale counts and smoother cranial lepidosis. It differs from 
prasinus, telenesetes and teriae in color, pattern, and hullshaped nuchal scales.

Description: The largest of the tree monitors, beccarii grows to $340 \mathrm{~mm}$ SVL.

The snout is long, depressed at tip, considerably narrowed anterior to nostrils. Canthus somewhat distinct, giving the snout a higher appearance than in other tree monitors. Nostrils round, median between snout tip and anterior edge of orbit. Upper labials flat, smooth and distinct, 22-23 in number. Cranials large, polygonal and smooth, with minute pits. Sutures between cranials deep, giving a predominantly rough texture (less so than in bogerti). Supraoculars 3-7, transversely elongated. Scales from rictus to rictus 32-37. Nuchal scales are hull-shaped, keeled.

Dorsal scales elongate, moderately keeled, especially along the flanks. Midbody scales in 81-86 rows. Ventrals in 70-79 rows, slightly keeled, of salvator-like structure (Fig. 3).

Adult SVL ranges from $150-340 \mathrm{~mm}$, TI 503-945 mm.

Scales uniformly black, with no trace of pattern. Ventral surfaces also black, sometimes grayish near axilla ang groin. The snout tip may be white in young specimens, from the rostral back three or four scales; in older specimens, this may become dark brown (preserved specimens). The head scales, 
especially the upper cranials and temporal scales, are glossy in texture. A table of tree monitor meristics is given (Tab. 2).

\section{DISCUSSION}

Monitor viridis was described by Gray (1831) based on a yellowish specimen without locality data. Schlegel (1839) examined a specimen from Fort de Bus on the western coast of New Guinea (=Irian Jaya) and renamed the species Varanus prasinus. Schlegel included a color illustration of the lizard in the accompanying atlas. Because Gray's type was lost and the identity of $\underline{\mathrm{M}}$. viridis unconfirmed, the specific name prasinus took priority.

Meyer (1874) described Monitor kordensis from wiak (=Kordo) Island, western New Guinea, based on its smaller dorsal scales, and a spotted, rather than banded, dorsum. DeRooij (1915) noted that the tail of kordensis was at least 2.33 times SVL, while it was under 1.75 times SVL in prasinus. Mertens $(1941,1942 \mathrm{C})$ recognized these characters as distinguishing kordensis from prasinus, but concluded that both taxa were similar enough to be conspecific. Mertens (1941) placed kordensis as a subspecies of prasinus, and maintained that position in a family review of varanids. The melanistic nonitor Beccarii was also described in 1874 (Doria, 1874), from Wokan, Aru Islands, south of western New Guinea. This species was distinguished on the basis of its black coloring and strongly keeled nuchal scales. The overall 
similarity in scale counts and morphology caused Boulenger (1885) to include it in his account of $\mathrm{V}$. kordensis; similarly, DeRooij (1915) failed to separate beccarii from kordensis in her account. Mertens (1941) noted the affinities, including enlarged supraoculars, elongated limbs and body, tail round in section, overlapping ventral and midbody scale counts, and geographic proximity and assigned beccarii as a subspecies of prasinus.

Mertens (1950) described Varanus prasinus bogerti from three specimens from Fergusson Island, Milne Bay Province, Papua New Guinea. It, too, is melanistic, distinguished from beccarii by higher ventral and midbody scale counts, rugose cephalic scales, and larger, tubercular nuchal scales.

Czechura (1980) discussed two monitors that were clearly allied to $\underline{\mathrm{v}}$. prasinus but did not fit existing subspecific descriptions. They represent three specimens from Queensland, Australia, and a single specimen from Rossell Island, Papua New Guinea, and are described as new species herein.

Mertens $(1942 \mathrm{a}, \mathrm{c})$ assigned the tree monitors to the subgenus odatria, containing "small species, under $1 \mathrm{~m}$. long, with rather short snout (except in prasinus, where it is decidedly long), and moderately high head, the nostril round or oval, almost always nearer the tip of the snout than the eye and... the tail is not laterally compressed...: supraoculars not much differentiated, except in the prasinus group; ...most with mesoprosopic, except prasinus, which has 
hypsirosopic...maxilla; nasals paired (except for prasinus)" (Mertens, 1942c, p. 240). A mesoprosopic snout would be square in section; a hypsirosopic snout would be triangular in section, with a broad base and narrow dorsal aspect.

MCDowell and Bogert (1954) also noted that the maxillary structure, which produces facial robustness in most odatrians, is nearly flat in $\underline{V}$. prasinus. Mertens distinguished prasinus from other odatrians by four characters; snout length, maxillary configuration, supraocular structure, and condition of the nasal bones.

An examination of odatrian monitors and the prasinusgroup reveals other morphological distinctions. Cranial lepidosis in odatria is small, pebbled in texture, and nearly uniform in size over the frontal-parietal region. In V. prasinus and its allies, these individual scales are larger, flat, polygonal, glossy, and smooth (though the depth of suture lines between individual scales gives an overall rugose texture in some taxa). The supraoculars are transversely enlarged, and quite distinct from the frontalparietal scales. The labial scales in odatrians are small and indistinct; in prasinus, they are larger, and well defined. Mertens (1942c, p.291) noted these features, and concluded that "prasinus seems unrelated to any recent monitors, being similar to no other species." 
This study disputes Mertens' assertion, and suggests the prasinus-group are closely allied to $\underline{v}$ indicus, and, less closely, to V. salvator. In contrast to odatria, the southeast Asian varanids tend to be larger, with compressed, slightly keeled tails. The limbs are longer, slender, and terminate in elongated digits. Their habitats tend to be mesic or semiaquatic. In morphology, they resemble prasinus in having similar cranial scalation, including flat, polygonal, glossy scales, and enlarged supraoculars. They also agree in having fused nasal bones, long snout, medial nostrils (salvator, karlschmidti, indicus) and flat maxillary region.

Bohme (1988) provided an exhaustive study of hemipenal morphology of lizards, and offered a taxonomic reassesment of varanids based on this character. He allies the prasinus-group and Varanus indicus in the subgenus Euprepiosaurus Fitzinger (1859) and supports an Indo-Australian epicenter for varanid origins. Baverstock (pers. comm.) confirms the prasinus, indicus and karlschmidti relationship based on antisera studies. Using data from Bohme (1986), Baverstock and 56 other presence/absence characters, this study confirms the affinities between the prasinus-group (to include prasinus, beccarii, bogerti, teriae, and telenesetes) and $\underline{\text {. indicus }}$ (Fig. 1).

In presenting hypotheses concerning varanid origins, it is generally accepted that monitors evolved in southeast Asia 
and dispersed from there (Mertens, 1942a; Storr, 1964; King and King, 1975; Holmes et al, 1975; Auffenberg, 1988). These studies have not been based on extensive examination of varanid characters, nor have they included the fossil specimens (Losos and Greene, 1989), although a review of fossil varanids has been presented (Estes, 1983a, b). In general, starting with Mertens (1942a), the Asian origins hypothesis has been based on the location of the greatest extant species diversity, greatest abundance of individuals, largest size of extant taxa, and most generalized ecologies, criteria largely abandoned for determining phylogenetic origins (Cain, 1944; Brown and Gibson, 1983).

In examining fossil varanid distribution and comparing fossil material with extant taxa, I formed an hypothesis that suggests varanids originated in northeastern Asia (Telmasaurus, Gilmore, 1943; Estes, 1983b; Borsuk-Bianynicka, 1984), dispersed quickly into northwestern North America (Saniwa, Gilmore, 1928; McDowell and Bogert, 1954; Estes, 1983a, b; Zerova and Chkhikvadze, 1984), and migrated over time to follow the equator, in a southeasterly direction. This accounts for the abundance of North American and European fossil varanids, while suggesting that $v_{\text {. griseus }}$ and the African varanids are the most ancestral extant taxa. Additionally, it allows the prediction to be made that as one moves further east from Africa, varanids become more derived in character. The cladistic analysis of 58 traits provides a cladogram that precisely predicts such a distribution (Fig. 
1). In examining the $\underline{V}$. salvator branch of this cladogram, each species listed has a range that extends further west than the taxon above it. $\underline{v}$. indicus ranges from further west to further east than prasinus, but among the tree monitors the insular taxa each occurs further east than the taxon preceding it. $\mathrm{V}$. telenesetes, with its unique combination of traits, seems the most highly derived varanid.

However close tine $\underline{v}$. prasinus and indicus may be, there are at least seven characters that separate the two groups, so that indicus (and tentatively karlschmidti) are retained in the subgenus Euprepiosaurus, while the tree monitors are assigned the new subgenus Chondrovaranus.

The status of varanid subgenera is in need of further study, as only about half the recognized taxa have been subjected to detailed antiserum, hemipenal, karyotypic and morphometric analyses, and the suite of all these factors will be necessary to clarify infrafamilial relationships. This study presents data for only 25 taxa, undertaken to assess the systematic position of Chondrovaranus in relationship to other varanids. While these data support the subgeneric assignments of Bohme (1986), they are insufficient to verify or support a full revision of the subgeneric status of Varanus.

The decision to elevate subspecies to specific status was made on the basis of morphological distinctness and distribution. In so doing, I follow wiley (1981), seeing sympatry and hybridization as irrelevant to determining functional evolutionary entities. Whether one accepts current 
cladistic methodology or the traditional phylogenetics, the absence of observable hybrids can be use? to support specific designations. The allopatry of these taxa has resulted in producing organisms with clearly distinguishable characters and lineages, even among the patternless melanistic forms. Though many biologists resist descriptions based largely on color and pattern, such obvious traits are important and have already been used to erect new species (Myers and Daly, 1976; Storr, 1980). The variation of hue and pattern in $\underline{v}$. prasinus once used to separate two subspecies, is in fact widespread throughout the lizard's range, and represents dynamic variation within the taxon. Enough characters can be examined to show no clearly divisible prasinus entity from a kordensis entity if more than one character is used in the evaluation. Among Chondrovaranus, prasinus has the westernmost range, from the Vogelkopf Peninsula, and extends into the eastern islands of Milne Bay. Next is found beccarii from the Aru Islands, south of Irian Jaya in the west. V. teriae is found in Australia's Cape York Peninsula, and shows the closest affinities to $\underline{v}$. indicus with which it is sympatric. bogerti occurs off the northeast tip of Papua New Guinea on two islands, and $\underline{v}$. telenesetes is known from an island some $330 \mathrm{~km}$. further east. $\underline{V}$. prasinus is recorded for Bobo Island, about midway between Rossel Island and the eastern New Guinea mainland, making telenesetes the easternmost member of Chondrovaranus. For all prasinids, the nearest prasinid taxon in terms of geographic distribution is $\underline{v}$. prasinus. 
The status of some subgenera remains uncertain, but patterns are emerging to indicate that the most primitive taxa are African/west Asian, while the most derived species are Australasian. The basic affinities between species as determined by cladistic analysis of 58 traits strongly agrees with the "subgeneric" groupings obtained by karyotypic (Holmes et al., 1975), antisera (Baverstock, pers. comm.) and hemipenal (Bohme, 1988) examinations. The most striking difference between Bohme's (1988) results and my own is that he supports an Australasian origin for varanids, while I interpret my data to suggest an Asia Minor, or possibly European origin for extant varanids. Using features beyond just hemipenal morphology, this paper separates prasinid monitors from mangrove monitors $(\underline{V}$. indicus and $\underline{v}$. karlschmidti), but otherwise confirms most of Bohme's findings.

From these data, a model for prasinus evolution can be presented. In prasinids there is an elongation and narrowing of the snout beyond that seen in indicus and salvator. Limbs and digits of prasinids are longer and thinner than in salvator, though they clearly resemble salvator. Three of the five tree monitor taxa are melanistic, (cf. the arboreal $\mathrm{v}$. rudicollis, which in the adult stage is almost completely black). Insular melanism is seen in salvator from the Nicobar and Andaman Islands (Deraniyagala, 1944, 1961), but is rare in Odatria ( Varanus acanthurus insulanicus, known from a single specimen (Worrell, 1963); and V. tristis, which has a black 
head and body, and virtually indistinct rosette dorsal pattern (Cogger, 1975)) and the gouldii group (V. rosenbergi is characteristically dark, but retains a distinct pattern). Pattern in the salvator-related taxa involves small clusters of light scales that form indistinct circles and random spots, while in both the gouldii and odatria groups, these patterns become well defined rings and flower-shaped spots. The green tree monitor falls into the former category. Even individuals with a spotted pattern more closely resemble the salvator or indicus pattern than they do either of the Australian groups. Tail length in tree monitors exceeds 200 per cent of SVL; in odatrians and $\underline{V}$.gouldii, the tail tends to be shorter than 110 per cent of SVL (an exception is the odatrian V. glebopalma).

Nuchal lepidosis in $\underline{V}$. beccarii and bogerti is similar to that of rudicollis, consisting of highly keeled, triangular scales that are distinct both in size and texture surrounding scales. In the tree monitors, the scales are comparatively smaller than in rudicollis.

Ecologically, Chondrovaranus are arboreal inhabitants of humid forests (Cogger, 1975; Czechura, 1980). This is similar to the salvator and indicus groups, but quite different from the terrestrial gouldii and odatria groups, which tend to be found in xeric habitats (Cogger, 1975; Storr, 1980).

The evolution of Chondrovaranus, from salvator stock leading to the closely allied indicus stock would be a more parsimonious explanation than the secondary dispersal from 
odatrians presented by Mertens (1942) and Storr (1964). Indicus is unusual in that, along with olivaceous, it is the only non-prasinid with green pigmentation, though this is often so dark as to appear black. The coloration of indicus is quite similar to that of teriae. In analzying varanid antigens and antisera, Baverstock (pers. comm.) confirms the affinites between prasinids and the water monitors, particularly karlschmidti and indicus, while Bohme's (1988) hemipenal study similarly links prasinids with indicus. Though indicus ranges from Indonesia east to the Solomons and north to Guam, all except teriae are New Guinea species.

In addition to the features described above, odatria is characterized by round tails, with distinctly keeled to spinose lepidosis. The limbs tend to be short and stout, as are the digits. Ecologically, they inhabit xeric or marginally mesic areas (Mertens, 1942a, b; Worrell, 1963; Cogger, 1975; storr, 1980). All these features suggest odatria is derived from gouldii-group ancestors, not the other way around, as suggested by others (Mertens, 1942; Storr, 1964; King and King, 1975; Auffenberg, 1988). Consequently, for reasons of morphology, ecology, distribution and biochemistry, prasinids must be removed from inclusion with odatria, and are herein placed in their own subgenus, Chondrovaranus.

\section{ACKNOWLEDGEMENTS}

I extend thanks to those curators who allowed me access to specimens: Richard Zweifel, Walter Auffenberg, Ernst Williams, William Duellman, George Zug, Jeannette Covacavich, 
Gregory Czechura, Darryl Frost, Harry Greene, Robert Drewes, Clarence McCoy, and Hymen Marx. For discussions leading to clarification of ideas and procedures I thank Joseph Collins, Harry Greene, Jacques Gauthier, Samuel McDowell, Robert Hassur, and Vida Kenk. For access to live lizards, I am grateful to Ron Roper and Rudolf Maengkom. Wayne Savage and Serena stanford arranged a grant from the society of Archimedes, San Jose State University, for part of this research. Teri sprackland contributed considerable amounts of time and money towards this research. Jacques Gauthier and Alan Leviton kindly provided work space and access to the PAUP computer program used for cladistic analyses. Jens Vindum, Robert Drewes and Harry Greene provided facilities during the study. This paper was submitted in partial fulfillment of the requirements for the degree of Master of Arts in Biology from San Jose State University.

\section{LITERATURE CITED}

Allison, Allen. 1982. Distribution and ecology of New Guinea lizards. Monographie Biologicae 42:803-813.

Auffenberg, walter. 1980. The behavioral ecology of the Komodo monitor. Univ. Florida Press, 1-406.

- 1988. Gray's monitor lizard. Univ. Florida Press, 1-419.

Bohme, Wolfgang. 1988. Zur genitalmorphologie der sauria: funktionelle und stammesgeschichtliche aspekte. Bonner 20ol. Monogr. 27:1-176.

Borsuk-Bianynicka, M. 1984. Anguimorphs and related lizards from the late Cretaceous of the Gobi Desert, Mongolia. Paleontologica Polonica 46:5-105. 
Boulenger, George. 1885. Catologue of the lizards in the British Museum (Natural History). Vol. II.

- batrachians from Ferguson Island, D'Entrecasteaux Group, British New Guinea. Ann. Mag. Nat. Hist. $16($ ser.6)

Branch, W.R. 1982. Hemipeneal morphology of platynotan lizards. J. Herp. 16:16-38.

Brown, J.H., and A.C. Gibson. 1983 Biogeography. Mosby Publ., 1-643. St. Louis.

Burt, Charles, and M. Burt. 1932. Herpetological results of the Whitney South Sea expedition. VI. Pacific island amphibians and reptiles in the collection of the American Museum of Natural History. Bull. Amer. Mus. Nat. Hist. 63:461-595.

Cain, S.A. 1944. Foundations of plant geography. Harper, New York.

Cogger, Harold. 1975. Reptiles and amphibians of Australia. Reed Pty, Ltd., Sydney.

Czechura, Gregory. 1980. The emerald monitor, Varanus prasinus (Schlegel): an addition to the Australian mainland herpetofauna. Mem. Queensland Mus. 20:103-9.

Deraniyagala, Paul. 1944. Four new races of the kabaragoya lizard, Varanus salvator. Spolia Zeylonica $24: 59-62$.

- 1961. The water monitor of the Andaman islandsa distinct subspecies. Ibid 61:78-85.

DeRooij, Nelly. 1915. The reptiles of the Indo-Australian archipelago. I. Lacertilia, Chelonia, Emydosauria. E.J.Brill, Leiden.

Doria, G. 1874. Enumerazione dei rettili raccolti dal Bott. G. Beccari in Amboina. Ann. Mus. Civ. Stor. Nat. Genova $6: 325-357$.

Estes, R. 1983a. The fossil record and early distribution of lizards. In A.G.J. Rhodin \& K. Miyata (eds), Advances in Herpetology and Evolutionary Biology: Essays in Honor of Ernest E. Williams:365-398. Cambridge, Museum of Comparative Zoology. 
1983b. Sauria terrestria. Hanbuch der

Paleoherpetologie, vol. 10a. Stuttgart: Gustav Fischer Verlag.

Gilmore, C.w. 1928. The fossil lizards of North America. Mem. Natl. Acad. Sci., 22:1-201.

- 1943. Fossil lizards of Mongolia. Bull. Amer. Mus. Nat. Hist., 81:361-384.

Gray, John. 1831. A synopsis of species of the class Reptilia. In Griffith, Animal Kingdom, vol. 9. London.

Greene, Harry. 1986. Diet and arboreality in the emerald monitor, Varanus prasinus, with comments on the study of adaptations. Fieldiana:Z001. 31:1-12.

Holmes, R., M. King and D. King. 1975. Phenetic relationships among varanid lizards based upon comparative electrophoretic data and karyotypic analyses. Biochem. Syst. Ecol. 3:257-262.

King, M. \& D. King. 1975. Chromosomal evolution in the lizard genus Varanus (Reptilia). Austr. I. Biol. Sci. 1975:89-108.

Losos, J.B. \& H.W. Greene. 1989. Ecological and evolutionary implications of diet in monitor lizards. Biol. Journ. Linn. Soc. 35:379-407.

McDowell, Samuel, and C. Bogert. 1954. The systematic position of Lanthanotus and the affinities of the anguinomorphan lizards. Bull. Amer. Mus. Nat. Hist. 105: 1-142.

Mertens, Robert. 1941. Zwei neue Warane des australischen faunengebietes. Senckenbergiana 23:266-272.

- 1942a. Die familie der warane (Varanidae). Erster teil: allgemeines. Abh. Senck. Naturf. Ges. $462: 1-116$.

- 1942b. Die familie der Warane (Varanidae). Zweiter teil: der schadel. Nbh. Senck. Naturf. Ges. $463: 117-234$.

- - - 1942c. Die familie der Warane (Varanidae). Dritter teil: taxonomie. Abh. Senck. Naturf. Ges. 465:235-365. 
- 1950. Notes on some Indo-Australian monitors (Sauria: Varanidae). Amer. Mus. Novitates 1456:1-7. 1959. Liste der Warane Asiens und der IndoAustralischen Inselwelt mit systematischen bemerkungen. Senck. Biol. 40:221-240.

Meyer, A.B. 1874. Subclass amphibia pholidota. Mon. Berlin Akad. p. 131 .

Myers, Charles, and J. Daly. 1976. Preliminary evaluation of skin toxins and vocalizations in taxonomic and evolutionary studies of poison-dart frogs (Dendrobatidae). Bull. Amer. Mus. Nat. Hist. $157: 175-262$.

Pregill, G., J. Gauthier, and H. Greene. 1986. The evolution of helodermatid squamates with description of a new taxon and an overview of Varanoidea. Trans. San Diego Soc. Nat. Hist. 21:167-202.

Schlegel, H. 1839. Abbildungen neuer oder unvollstandig bekannter amphibien (text, atlas). Dusseldorf.

Storr, Glenn. 1964. Some aspects of the geography of Australian reptiles. Senck. Biol. 45:577-589.

------. 1980. The monitor lizards (genus Varanus Merrem, $1820)$ of Western Australia. Rec. West. Aust. Mus. $8: 237-293$.

Wiley, Edward. 1981. Phylogenetics, the theory and practice of phylogenetic systematics. John wiley, NY, 1-439.

Worrell, Eric. 1963. Reptiles of Australia. Angus \& Robertson, Sydney.

Zerova. G.A. \& V. Chkhikvadze. 1984. Review of Cenozoic lizards and snakes of the U.S.S.R. Izvestiya Akad. Nauk. Gruz. SSR (Biol.), 10:319-326. 
TABLE 1. Character states and coding for 23 species of Varanus.

1. Nostril round (0) or slit-like (1).

2. Nostril posterior (0), median (1) or anterior (2) in position.

3. Nostril lateral (0) or dorsal (1).

4. Nostril region not swollen (0) or swollen (1) in appearance.

5. Nostril without (0) or with (1) a valve.

6. Nasal bones fused (0) or separate (1).

7. Closed mouth forms distinct seam (0) or is tight and seamless (1).

8. Tongue short (0) or long (1).

9. Tongue dark (0) or light (1) in color.

10. Snout broad (0) or narrow (1) at tip.

11. Snout depressed (0) or high (1).

12. Snout blunt ( 0 ) or acute (1) in adults.

13. Gular scales flat (0) or conical (1).

14. Eyelids with normal (0) or slightly fringed (1) scales.

15. Preocular streak present (0) or absent (1).

16. Postocular streak present $(0)$ or absent (1).

17. Supratemporal arch thin (0) broad (1) or absent (2).

18. Supraocular scales subequal, small (0) or dilated, larger than interorbital scales (1).

19. Cranial scales flat, non-reflective (0) or glossy (1).

20. Cranial scales large, polygonal (0) or small, pebbled (1).

21. Cranial surface rough $(0)$ or smooth (1).

22. Canthus rostralis rounded (0) or distinct (1).

23. Snout boxlike (0) or triangular (1) in section.

24. Nuchal scales subequal to dorsals $(0)$ or larger than dorsals (1).

25. Nuchal scales rounded (0), keeled (1) or very keeled (2).

26. Nuchal area banded (0) or unbanded ( 1 .

27. Nuchal scales smaller or equal to occipital scales (0) or larger than occipital scales (1).

28. Neck length moderate (0) or elongate (1).

29. Dorsal scales uniform, subequal (0) or heterogenous (1).

30. Dorsals small (0) or large (1).

31. Dorsum patterned $(0)$ or unpatterned (1).

32. Digits with enlarged terminal scale (0) or not (1).

33. Claws conical (0) or compressed (1).

34. Ventral scales smooth (0) or keeled (1).

35. Ventral scales rectangular $(0)$ or oblong (1).

36. Adpressed 1 imbs meet (0) or do not meet ( 1 ).

37. Preanal pores absent (0) or present (1).

38. Ventral caudal scales larger or equal to dorsal caudals (0) or smaller than dorsal caudals (1).

39. Caudal scales irregular (0) or form bands of annuli (1).

40. Tail slightly (0) or fully (1) prehensile.

41. Caudal scales glossy, slightly keeled $(0)$ or strongly keeled (1).

42. Tail length greater than (0), equal to (1) or less than (2) snout-vent length. 
43. Tail round $(0)$, approximately half round (1) or compressed (2) in section.

44. Tail lacking dorsal keel (0), or having double dorsal keel (1) .

45. Tail banded (0) or unbanded (1).

46. Tail completely [100\%] banded (0) or less than completely banded (1).

47. Parietal bone slightly (0) or greatly (1) constricted medially.

48. Gular fold absent (0) or present (1).

49. Ear exposed (0) or concealed (1).

50. Nasal bones dorsally with tabllike surface $(0)$ or knifelike (1) .

51. Karyotype group A (0), B (1), C (2), D (3), E (4), or F (5) [data from Holmes, King \& King, 1985].

52. Hemipenal group A (0), B (1), C (2), D (3), E (4), F (5), $G(6)$ or $H(7)$ [data from Bohme, 1986].

53. Antisera group A (0), B (1), C (2), D (3), E (4), F (5), or G (6) [data from Baverstock, pers. comm.].

54. Size range 0.1-0.5 M (0), 0.6-0.9 M (1), 1-1.5 M (2), over $1.5 \mathrm{M}(3)$.

55. Ventrally mottled $(0)$ or solid (1) in color.

56. Ecology primarily fossorial/terrestrial (0), arboreal (1) or aquatic (2).

57. Palmar surfaces lacking (0) or possessing conical processes (1).

58. Palmar surfaces pale (0) or black (1).

Taxon Character state coding

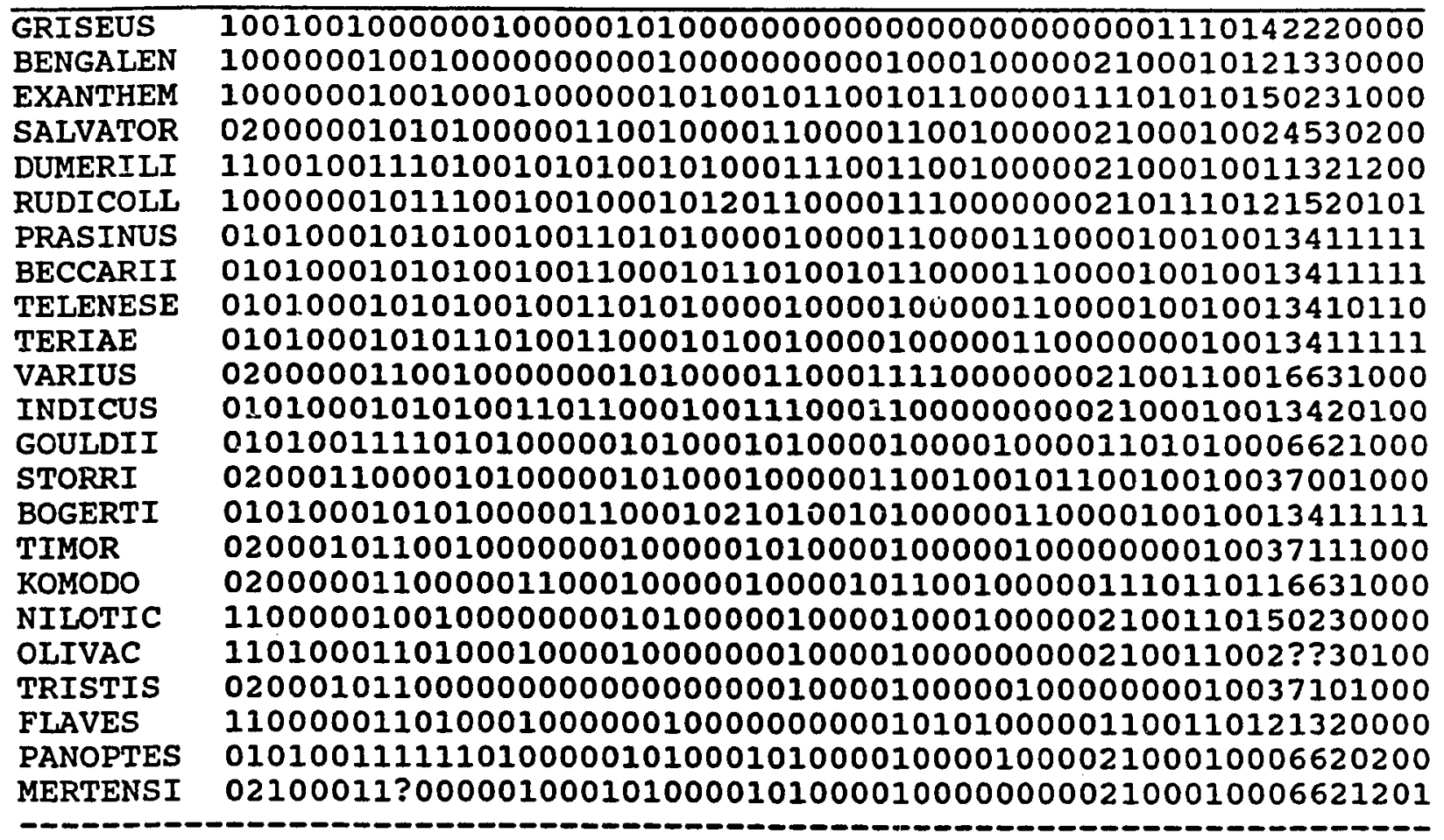


Table 2. Comparative characters in tree monitors.

\begin{tabular}{lrrrrr} 
& telenesetes & teriae & prasinus & bogerti & beccarii \\
\cline { 2 - 5 } \#ventrals & 92 & $84-91$ & $71-90$ & $87-90$ & $70-79$ \\
\#midbody & 100 & $90-93$ & $80-112$ & $95-99$ & $81-86$ \\
\#rictals & 40 & 36 & $32-42$ & $44-48$ & $32-37$ \\
Nuchals & sl.keel & sl.keel & smooth/ & tubercular & keeled \\
Cranials & smooth & sl.rugose smooth & rugose & sl.rugose \\
Gulars & flat & conical & flat & flat & flat \\
Palms & pale & black & black & black & black \\
Ventor & mottled & green & green & black & black \\
Dorsum & green & black & green & black & black \\
Pattern & yes & yes & yes & no & no \\
Ventrals & smooth & smooth & sl.keel & smooth & sl.keel
\end{tabular}




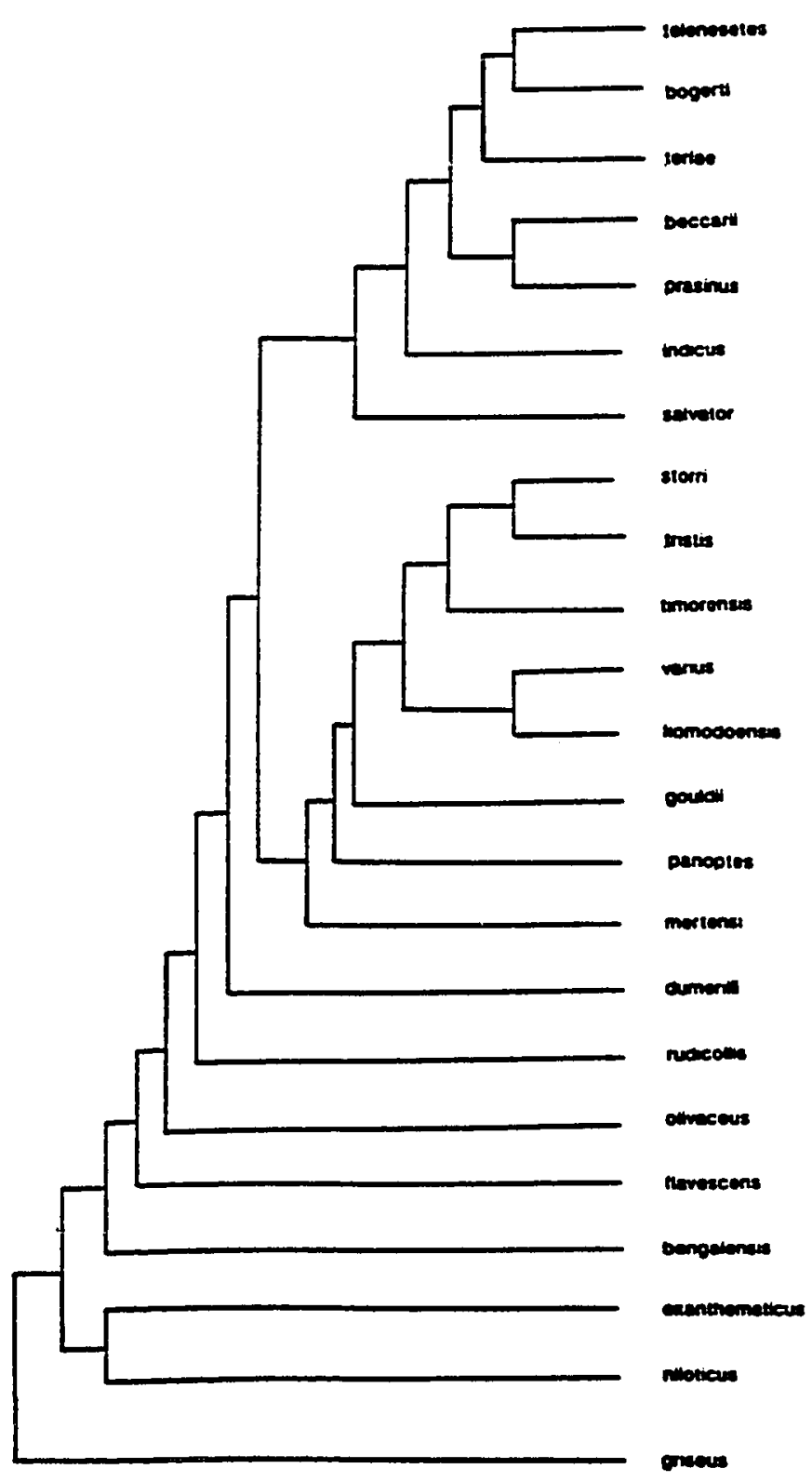

Fig. 1. PAUP produced cladogram of Chondrovaranus group and 18 other varanids. Data matrix is presented in Table 1 . The geographic range for each taxon extends further east as one moves up the cladogram. See discussion for details of subgeneric implications. 


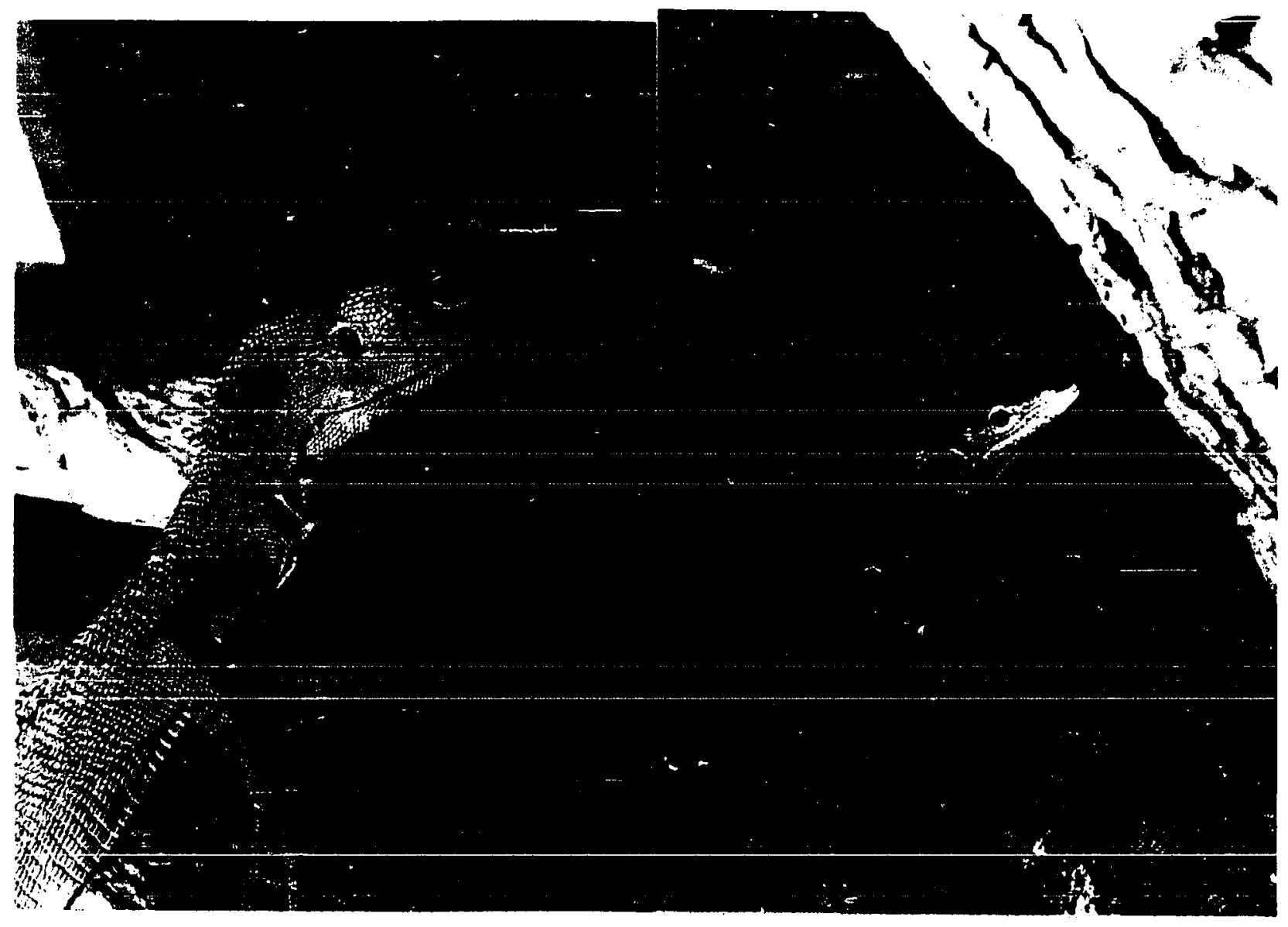

Fig. 2. Varanus prasinus, showing banded (left) and rosette (right) dorsal patterns. The latter was previously assigned to the subspecies $\mathrm{V}$. $\mathrm{p}$. kordensis, placed in junior synonomy in this paper. Monitor at left from author's collection; at right, photographed at oklahoma city zoo. 

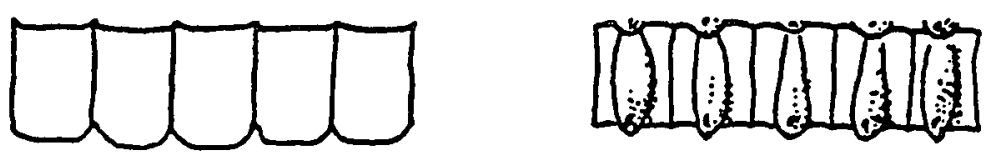

Fig. 3. Ventral scales of Varanus salvator (left) and $\underline{V}$. varius, showing the two distinct morphologies of these scales in adult varanids. Chondrovaranus has the salvatortype scalation.

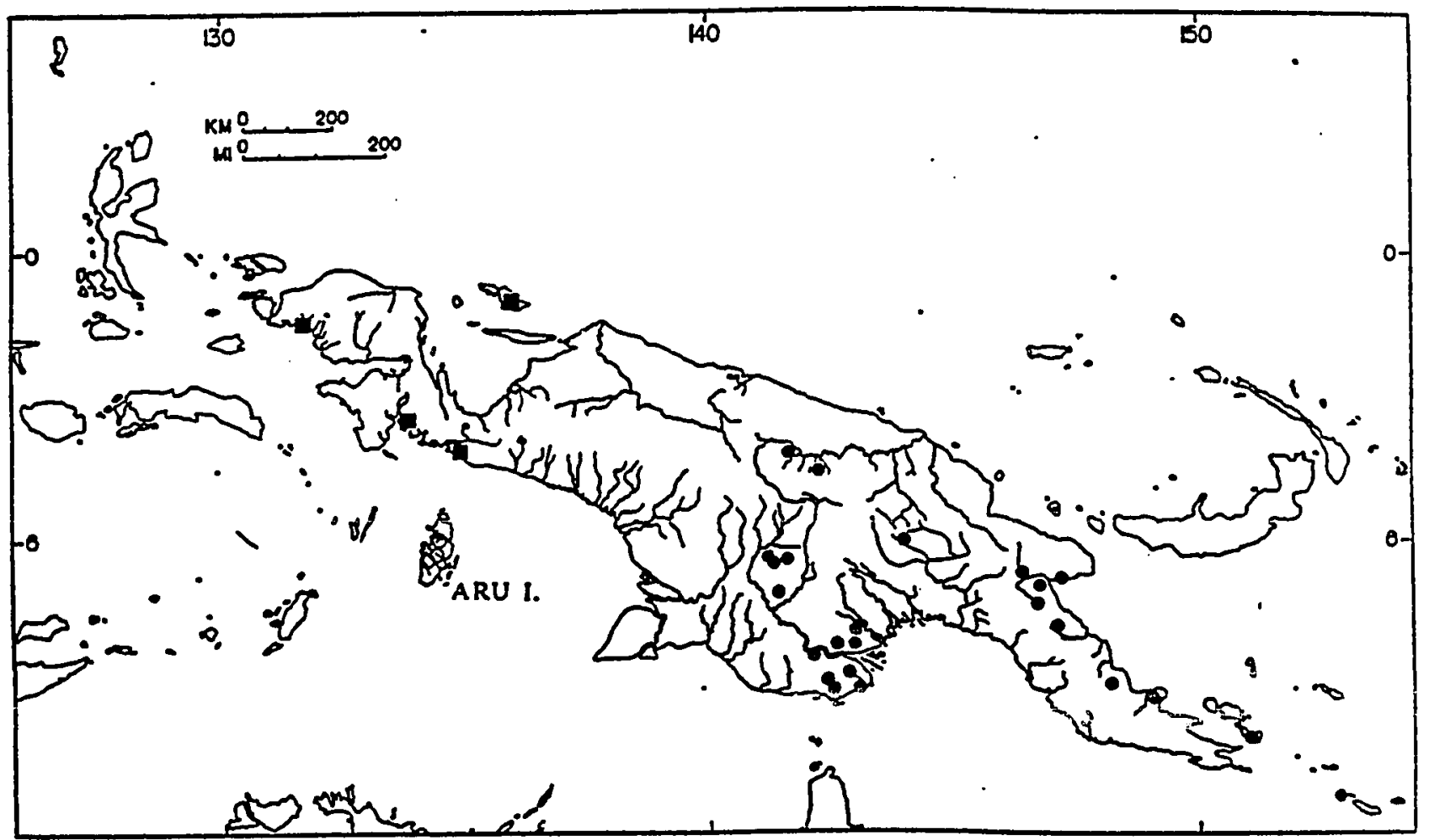

Fig. 4. Range map for Varanus prasinus (circles are localities examinied by author; squares are localities from the literature) and $\underline{V}$. beccarii (open circles, Aru Islands). Both taxa occur in lowland forests up to 1500 feet. 


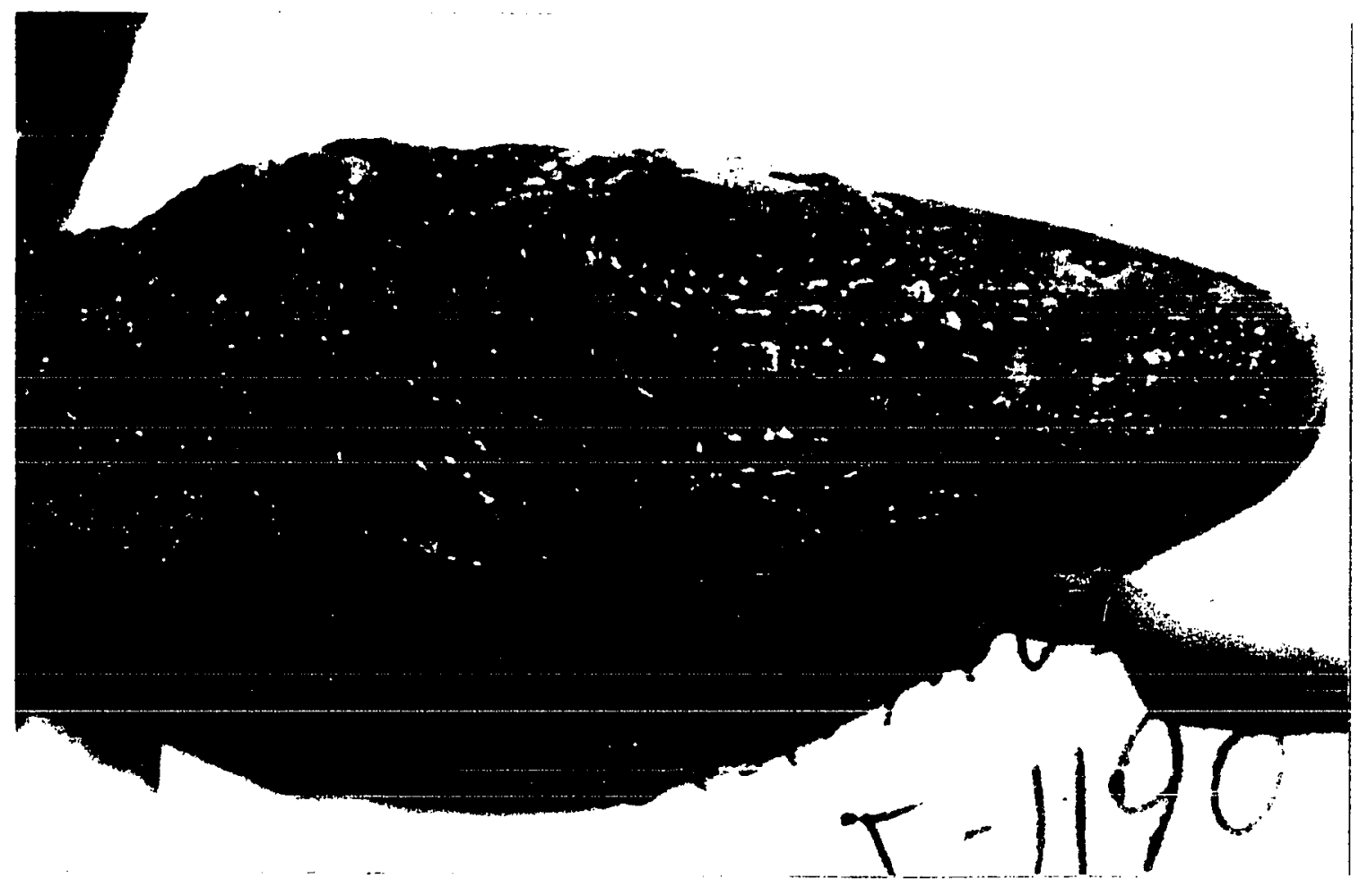

Fig. 5. Varanus telenesetes, sp. nov., holotype, QD J1190, dorsal view of head. 


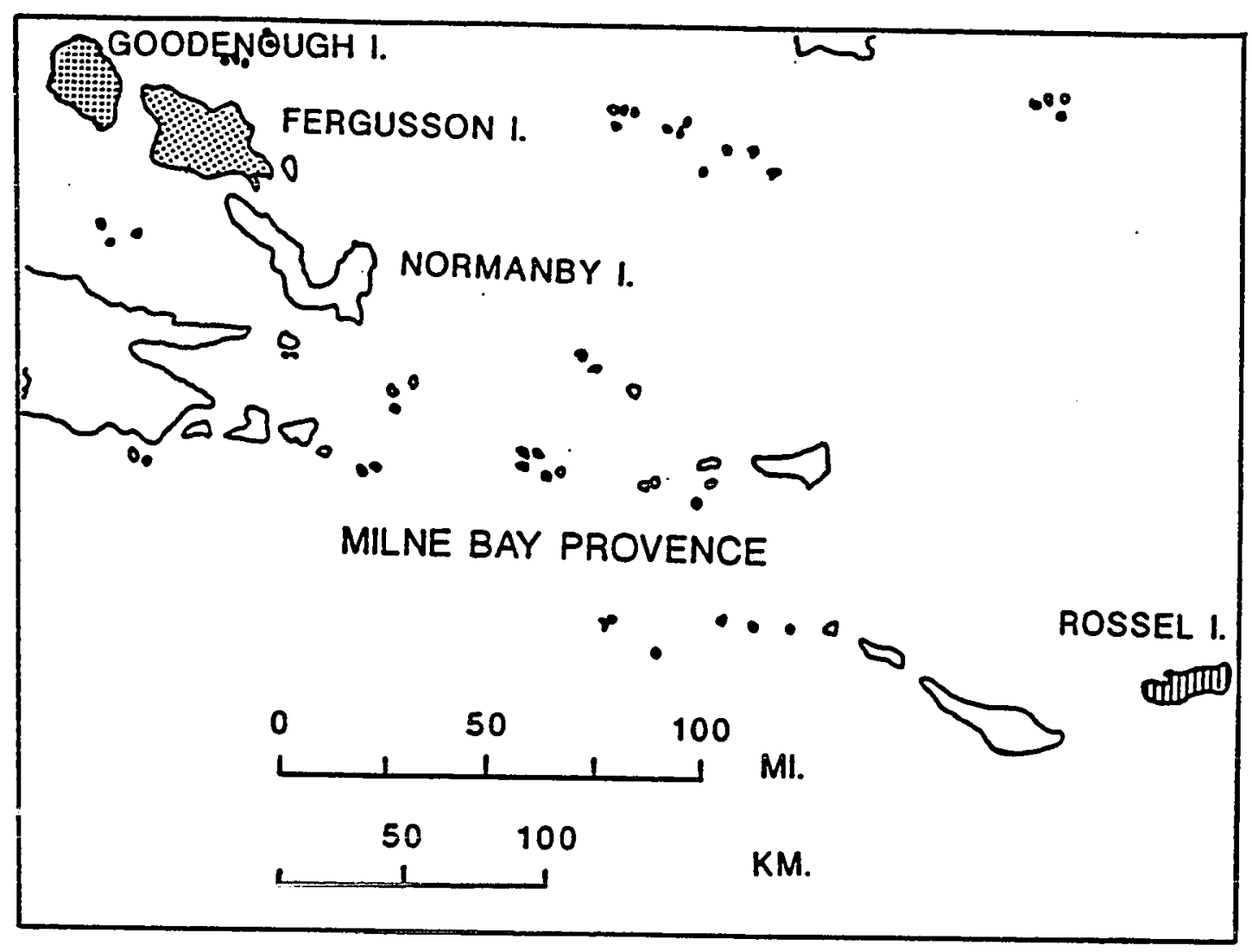

Fig. 6. Range map for Varanus bogerti (stippling) and $\underline{V}$. telenesetes (lines) in eastern Papua New Guinea. 

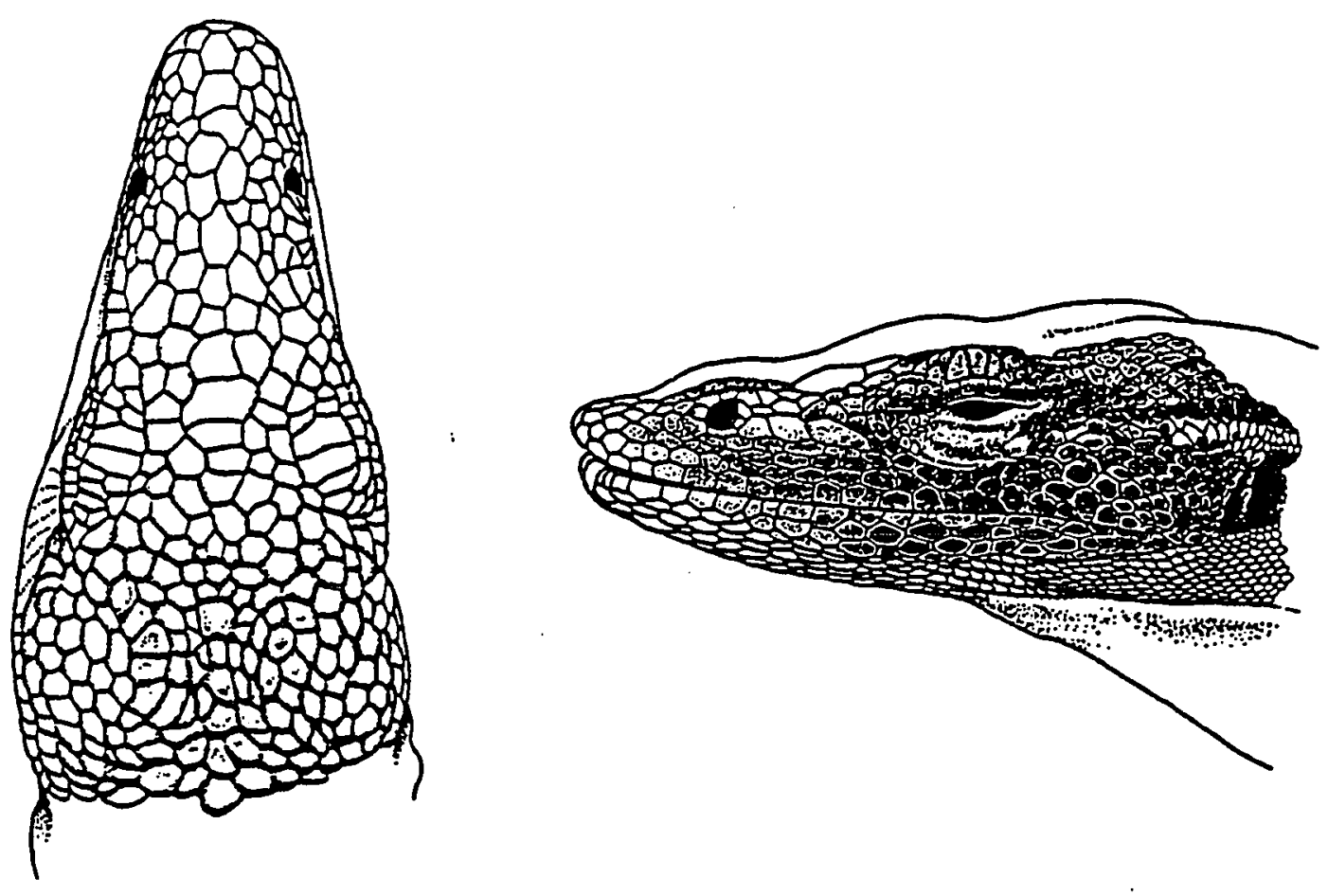

Fig. 7. Varanus teriae, sp. nov., from the holotype. Drawn by Jeff Boundy from photos by the author. 


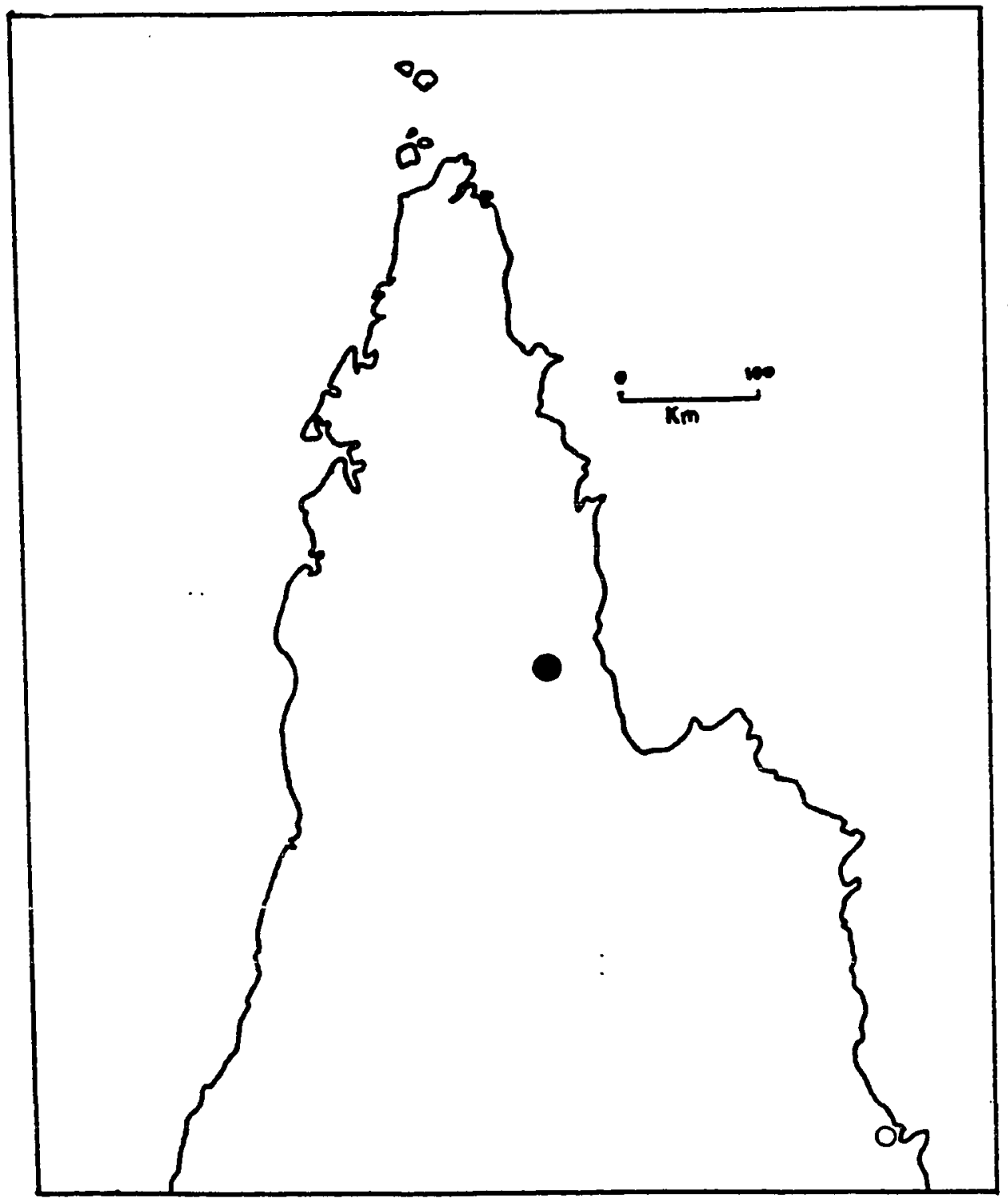

Fig. 8. Range map for Varanus teriae, near Coen, Queensland, Australia. The open circle represents Cairns. 


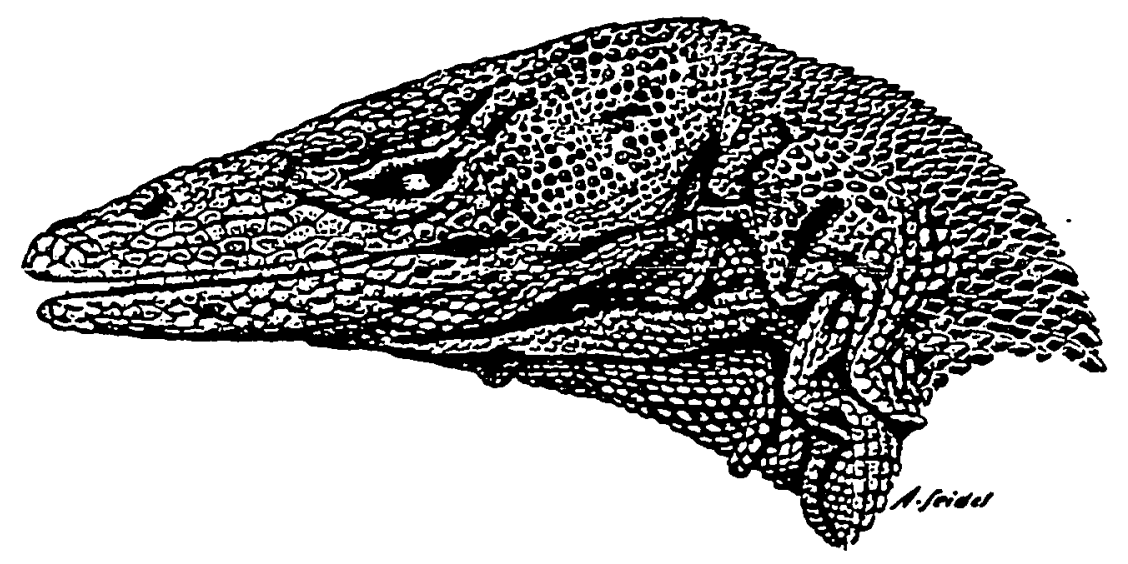

Fig. 9. Varanus bogerti, from Mertens (1950).

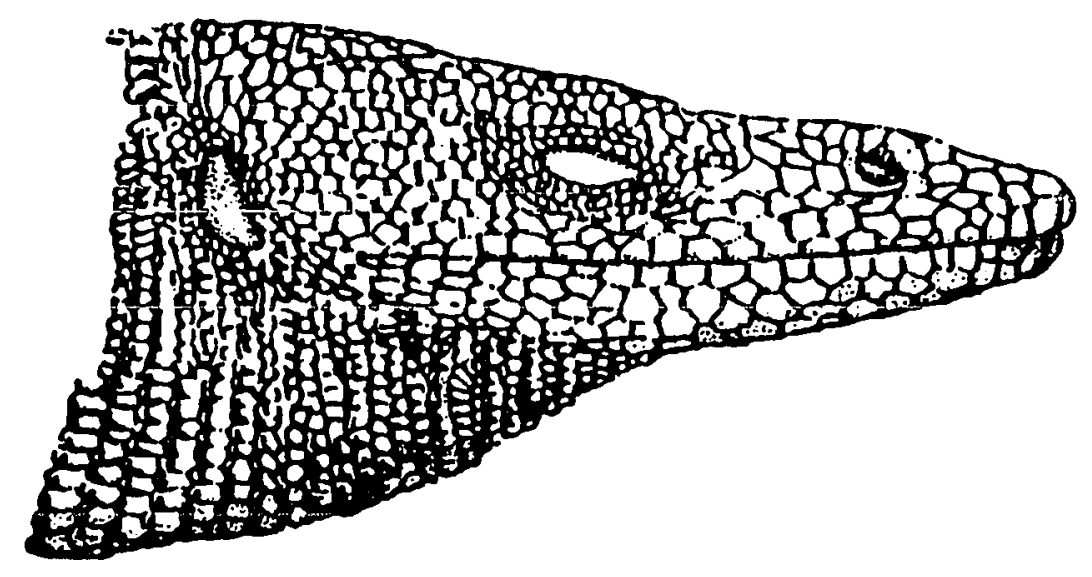

Fig. 10. Varanus beccarii, from type description by Doria (1874). 